\title{
A DESCRIPTIVE STUDY TO ASSESS ORAL HEALTH STATUS AND ORAL HYGIENE PRACTICES AMONG SCHOOL GOING CHILDREN IN A SELECTED SCHOOL OF MUMBAI
}

\author{
DEEPA GANESH REDDY, SAPNA NAIR, SWATI SHIRSATH, ANJALI JADHAV, BHAVANA GURAV \\ \& MARIA MATHEW \\ Department of Child Health Nursing, D.Y. Patil University School of Nursing, Maharashtra, India
}

\begin{abstract}
Background of the Study: OHS is often determined by the amount deposited on the surface of the teeth and poor oral hygiene can lead to the various oral and dental diseases like caries and plaque etc., so to overcome them oral hygiene practices related to brushing is important to be away from germ. The purpose of the study to assess oral health status and oral hygiene practices among school going children.

Methods: A cross sectional, descriptive study with quantitative perspective was conducted to assess the oral health status and determine the oral hygiene practices among school going children, rural school of Mumbai, Maharashtra. There were 200 respondents (119 were primary section and 81 were secondary section).Non-probability convenient sampling technique was adopted. The study was carried out through interview method using pre-designed and pretested questionnaire and oral assessment by observation method. (Part 1: Socio-demographic details; Part 2: OHAT were used for assess the oral health status and Part 3: Oral hygiene practice questionnaire). Validity and reliability of the tool was assessed. Interrater reliability was used for OHAT categories by using kappa statistics [carries, tongue, calculus almost perfect agreement $(k=1)$ and other aspects such as mobility, plaque, fluorides found to be moderate agreement $(k=0.54)]$ and interview questionnaire of oral hygiene practices by using Karl Pearson's correlation coefficient formula $(r=0.74)$.Data was collected and interpreted by using descriptive statistical analysis.

Results: The study sample comprised of 200 school going children age group of 6-12 years, in which 103 (51.5\%) were male and 97 (48.5\%) of them were female. There was slight difference in the gender. Among them112 (56\%) were living in a joint family and 88 (44\%) of them were from nuclear family. Majority of the respondents173 (86.5\%) belongs to Hindu religion and 27 (13.5\%) from other religion i.e., Muslim religion. All the respondents belong to the homogenous group i.e. Upper lower socioeconomic status.

In the present study shows that, majority of them having healthy soft tissue and mostly they has problem in hard tissue. Out of 200 subjects, $34.5 \%$ didn't have dental carries, $39.5 \%$ had changes in the teeth (1-3decay) and $25.5 \%$ had unhealthy status (>3 decay). For mobility $78.5 \%$ of the respondents didn't have any dental tooth or teeth mobility, 16\% had 1st and 2nd degree mobility and only 5\% had 3rd degree mobility. For plague $6.5 \%$ had no plague, $78 \%$ of the respondents had a thin film of plaque and $15 \%$ had abundance of plaque. For fluorosis $36 \%$ of the respondents had no complain of fluorosis, $36.5 \%$ had white patches on the teeth and $27 \%$ of the respondent had brownish discoloration of the teeth surface. Majority of respondents had no evidence of calculus I.e.81.5\%, whereas $16 \%$ had slightly traceable changes and $2.5 \%$ had moderate calculus.

In the present study, $87.5 \%$ not brushing twice in a day, $4 \%$ of the study subjects not using tooth brush instead of that they are using fingers for brushing, 95.5\% has poor brushing techniques, 32\% don't rinse their mouth after meal, $23.5 \%$ don't have cleaning practice of tongue, 70\% clean the tongue by using tongue cleaner, 55\% of the study subjects didn't use of fluoride content tooth paste, $78 \%$ brushing less than 1 minutes, 56.5\% using of hard medium
\end{abstract}




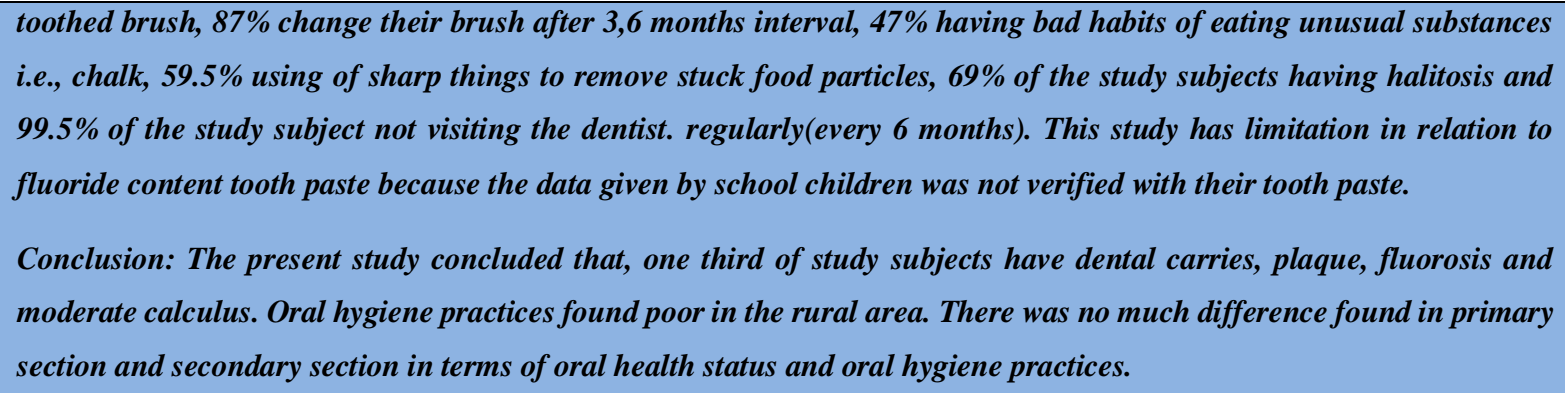

Received: Jun 06, 2020; Accepted: Jun 26, 2020; Published: Aug 24, 2020; Paper Id.: IJMPERDJUN2020862

\section{INTRODUCTION}

Oral health is a key indicator of overall health, wellbeing and quality of life. WHO defines oral health as "a state of being free from chronic oral infections/mouth and facial pain, sores, periodontal disease, dental caries, tooth loss and other disease that limit and individual's capacity in biting, chewing, smiling, speaking and psychosocial wellbeing". ${ }^{9}$ Poor oral health has severe complication which may affect an individual's behavior at school, home, and in working area.

The Global Burden of Disease study 2016 evaluated that oral disease affected half of the world's population (3.58 billion people) with dental caries (tooth decay) in permanent teeth being the most prevalent condition assessed. Globally, it is estimated that 2.4 billion people suffer from caries of permanent teeth and 486 million children hurt by caries of primary teeth. ${ }^{1}$

According to WHO (2012), dental caries is a high prevalent oral disease in worldwide as well as several Asian and Latin- American countries, while it appears to be less common and less severe in most African. Tooth decay is still a major oral health problem in most developing countries, affecting $60-90 \%$ of school children and the vast majority of adults. ${ }^{10}$

Oral disease can be considered a community problem due to their high prevalence and significant social impact. According to National Commission on macroeconomics and health, the prevalence of dental caries in India is 50\%-60\%. Various studies report varying levels of prevalence in India ${ }^{4}$. In the National health survey conducted in 2004 throughout India, it has shown dental caries were found $51.9 \%$ in 5 year old children, $53.8 \%$ in 12 year old children. ${ }^{8}$ Thus; it becomes important to assess the oral health status.

A study of oral hygiene practices and oral health status among school children in 2016, Jabalpur, (Shashi Praha Tomaretal.,). 1000 students were participated in the study. The researchers reported regarding oral practices, $61.7 \%$ of them brush in the morning, $34 \%$ children had habit of brushing both time morning and at night before going to bed. Only $22 \%$ of children used correct brushing technique. Most common malpractices among children were eating chalk $12 \%$. Regarding oral health status of school children, $54.7 \%$ were having dental caries most common problem found. So they concluded that of oral hygiene practices is important like brushing, frequency of brushing, frequency of changing the brush and brushing techniques, and use of mouthwash. ${ }^{2}$

A study was done to assess oral health status of 5, 12, 15 year old school children in Tiruvalla, Kerala India, by Benley George and Vinod Mathew. Researcher used stratified cluster sampling technique for selection of 39 schools in geographical region, period of May 2013 to May 2014. A total of 5688 students were screened, out of that 1623 students were 
5 years old, 1936 were 12 years old and 2129 were 15 year old students. A pretested questionnaire was distributed 2 days before the survey in each school. Study revealed that majority (73.9\%) of the 12-year student had healthy gingival. Results revealed that among girls, $21.8 \%$ had calculus and $2.5 \%$ had bleeding gums. Among boys $24.3 \%$ had calculus and $3.1 \%$ had bleeding gums. The Prevalence of dental caries was highest among 5-year students who belong to poor socio-economic status $(41.5 \%)^{3}$

The survey was conducted on prevalence of dental caries and oral hygiene practices in school children aged 7 to 12 years by Dr M.S. Minor Babu, et.al, at Nellore district in the year 2011. The survey was carried out in 1590 children of 20 schools in rural and urban areas. Out of this 796 were male and 794 were female children. The DMFT and deft indices were used to assess the number of decayed, missing and filled teeth and surface for the permanent dentition as well as the primary dentition. Overall prevalence of dental caries was $65.5 \%$. High prevalence of dental caries was found among urban school children than rural. Among them oral hygiene status was poor in rural school children than urban. So the study concluded that prevalence of dental caries was higher in urban school children even with good oral hygiene practice than rural school children. $^{7}$

Oral health status is highly depending on the oral hygiene practices of keeping the teeth clean and germ free. According to American dental association (ADA), children should have first visit of dentist afterthe age 6 month after that every 6 months should visit the dentist on regular basis fordental checkup and sometime cleaning and it is important to avoid further consequences. Data from previous studies indicates that the many of them visit dentist only for treatment purpose. The study concluded that $>70 \%$ of Indian population has a poor awareness on oral health and practices than urban. (S Garg) ${ }^{6}$

The survey was conducted in the year 2011 in western suburbs of Mumbai, India (Mehta Amrita, et.al). A total of 169 children between the age of 7 and 17 were them involved in the survey. The studies were focused on oral hygiene practices by using open and closed ended questionnaire. The results mentioned that majority of them using toothpaste and only $2 \%$ usingmanjan to clean their teeth, $52 \%$ used horizontal technique to brush their teeth, $47 \%$ of them changed their brush monthly and $49 \%$ don't know, thus shows that only few of them change their brush quarterly, $75 \%$ of them cleansed their tongue out of which $85 \%$ use tongue cleaner and $40 \%$ used tooth brush, $72 \%$ of them were aware about who is dentist and $28 \%$ didn't knew it, $85.5 \%$ consume frizzy drinks and $14.5 \%$ of them did not consume. None of them were aware about fluoride and floss. ${ }^{5}$

The above review of literature stated that, dental caries is the most common problem due to poor oral hygiene practices both versus urban and rural even though good practices in urban comparatively. There is increase need of assessing oral health status of children at early age to prevent complication in the future. Hence the researcher decided to conduct this type of study in Mumbai to identify the magnitude or burden of oral health problem among the school going children. If oral health problem are detected at early stage it can be corrected by visiting dentist and oral health problem can be prevented by following correct oral hygiene practices. 


\section{MATERIALS AND METHODS}

A cross sectional, descriptive study with quantitative perspective was conducted to assess the oral health status and determine the oral hygiene practices among the school going children in rural school of Mumbai, Maharashtra. There were 200 respondents (119 were primary section and 81 were secondary section). Non-probability convenient sampling technique was adopted.

The present study was approved by the Research Ethical Committee. As per ethical committee suggestion, the researcher was taken training before proceeding data collection from Dr Ajay Mathur, dentist, consultant of Fortis Hospital heath care ltd., to carry out assessment of oral health status among school children with skillfully.

Conceptual model based on system theory (1975) was used. In that, input consider as a tool includes Part 1: Socio -demographic details; age, sex, residential address and economic status. Part 2: OHAT consists of assessment of soft tissue (i.e. gum and tongue) and assessment of hard tissue (i.e. carries, decay, plaque, flourosis, calculus) were used for assess the oral health status by using observation method with the help of gloves, ice cream sticks, torch, face mask. Part 3: Oral hygiene practice questionnaire such as technique of brushing, type of tooth brush and powder, tongue cleaning technique, tongue cleaning agent, time require for brushing which use to be perform at home which is reported by the respondents by using interview method. The process applied over in this study was carried out through interview method using pre-designed and pretested questionnaire and oral assessment by observation method. The outcome may be healthy or unhealthy or there might be some changes in oral health status. Oral hygiene may be healthy practices or unhealthy practices.

A pilot study was conducted on September 2018 to test the applicability and feasibility of the research design and the tools. The design and tools were found to be feasible. Validity and reliability of the tool was assessed. For validity, the tool was given to five nursing faculty of different speciality and 2 dentist. The tool was modified based on their valuable suggestion. Interrater reliability was used for OHAT categories by using kappa statistics [carries, tongue, calculus almost perfect agreement $(\mathrm{k}=1)$ and other aspects such as mobility, plaque, fluorides found to be moderate agreement $(\mathrm{k}=0.54)]$ and interview questionnaire of oral hygiene practices by using Karl Pearson's correlation coefficient formula ( $r=0.74)$ as per coefficient range the tool fell in strong relationship, Hence the tool was reliable.

The study was conducted in Z.P school, Chandranagar (ZilhaParishad Kendra Shala Chandranagar.) which is located in Vangaon under the care of Chandranagar (PHC). The selected school was feasible and convenient or the investigator to carry out the study. Formal permission obtained from school authority and from parents/guardians.

The researchers included all the students from class $1^{\text {st }}$ and $2^{\text {nd }}$ standard of Primary section and 5th\& 6th standard of secondary section. Children those who are fulfilling the following criteria: age between 6-12 years was selected for study purpose. Subjects those who were absent and those who not given the inform consent were excluded from the study. On the scheduled day, the researchers met all the students of each class and explained them the project and their required participation. Students were called one by one in the designated examination room.

Data was collected and interpreted by using descriptive statistical analysis. The school authorities were informed about children who had oral health problems. Based on the findings and the results, the children referred to dentist. In addition, the investigator gave health education on oral hygiene practices to all study subjects.

\section{RESULTS}


Table I represents that, out of 200 (N) 6-12 years old school going children, in which 103 (51.5\%) were male and 97 (48.5\%) of them were female. There was slight difference in the gender. Among them112 (56\%) were living in a joint family and 88 (44\%) of them were from nuclear family. Majority of the respondents173 (86.5\%) belongs to Hindu religion and $27(13.5 \%)$ from other religion i.e., Muslim religion. All the respondents belong to the homogenous group i.e. Upper lower socioeconomic status.

The first objective was to assess the oral health status among school going children data illustrated inFigure 1 and 2 , it's revealed that in the category of Soft tissue, $89.5 \%$ of the respondents had healthy gums, $6.5 \%$ had changes in the gums (rough and red in color) and 3.5\% had unhealthy gums (swollen gum bleeding). Then $98.5 \%$ of the respondent had healthy tongue and only $1.5 \%$ of them had changes (patchy, red \& ulcerated tongue).

The study shows that, in hard tissue $34.5 \%$ didn't have dental carries, $39.5 \%$ had changes in the teeth (1-3decay) and $25.5 \%$ had unhealthy status ( $>3$ decay). For mobility $78.5 \%$ of the respondents didn't have any dental tooth or teeth mobility, $16 \%$ had $1^{\text {st }}$ and $2^{\text {nd }}$ degree mobility and only $5 \%$ had $3^{\text {rd }}$ degree mobility. For plague $6.5 \%$ had no plague $78 \%$ of the respondents had a thin film of plaque and $15 \%$ had abundance of plaque. For fluorosis $36 \%$ of the respondents had no complain of fluorosis, $36.5 \%$ had white patches on the teeth and $27 \%$ of the respondent had brownish discoloration of the teeth surface. Majority of respondents had no evidence of calculus I.e.81.5\%, whereas 16\% had slightly traceable changes and $2.5 \%$ had moderate calculus. Primary section children were having more oral health problem than the secondary section children.

The second objective was to assess the hygiene practices among school going children and data was represented in table I, the following oral hygiene practices such as: Material used to clean teeth $96 \%$ of the respondent used toothbrush and toothpaste and $4 \%$ of the respondent used other material like toothbrush and toothpowder, finger and toothpowder, neem stick, datum Type of toothpaste, $11 \%$ of the respondent used herbal toothpaste whereas $89 \%$ used non herbal toothpaste. Frequency of brushing $12.3 \%$ respondent brushed twice a day, whereas $87.5 \%$ brushed once in a day. Respondent who used circular technique of brushing were $4.5 \%$ and $95.5 \%$ of them used horizontal and zigzag technique to brush. Practice of rinsing $68 \%$ of the respondent rinsed their mouth after meal whereas $32 \%$ of e respondent dint rinsed their mouth after meal. Practice of tongue cleaning $76.5 \%$ of the respondents cleans their tongue out of which $70 \%$ of them used tongue cleaner and $30 \%$ used other method to clean their tongue. $22 \%$ of the respondents brushed their teeth for $1-3$ min. and $78 \%$ brushed the teeth for < $1 \mathrm{~min}$. Type of tooth brush $43.5 \%$ of the respondents used soft tooth brush whereas 56.5\% used hard or medium tooth brush out of which $13 \%$ change their brush once in 3 months and $87 \%$ change their brush for $>3-6$ months.53\% of the respondents had bad eating habits, $47 \%$ didn't had any bad eating habits, $55 \%$ of the study subjects didn't use of fluoride content tooth paste, $69 \%$ of the respondents complained about halitosis whereas $31 \%$ of the respondents didn't had halitosis .And only $0.5 \%$ of the respondents visited dentist regularly and rest $99.5 \%$ only visit dentist when there was a dental problem. There was no much statistical difference in the oral hygiene practice followed by the primary and secondary section. This study has limitation in relation to fluoride content tooth paste because the data given by school children was not verified with their tooth paste.

\section{DISCUSSIONS}

Oral health is essential for one's overall wellness and it is an integral part of one's physical, social and mental wellness being. It is very important to instill good oral health practices from a young age to ensure long-term dental health and hygiene. 
A cross sectional study was conducted to assess oral health status and oral hygiene practices in school going children in Mumbai. The study sample comprised 200(N) 6-12 year old school going children in Mumbai. According to the present study the prevalence of dental carries is $39.49 \%$ which is more than the study carried out by Shashi Prabha which showed 31.7\% and AnuPriya Slena which showed 58.4\%. The observed rate is lower than with the studies conducted by Anand Hirenath who reported it being $78.9 \%$.It was also noted that bleeding gums rate was only 4.2 in primary section is less than in secondary and $2.5 \%$ had moderate calculus but the study conducted by B Barley Matthew reported11.1\%had bleeding gums and $56.1 \%$ had calculus These difference in the observation may be due to the research methodology difference in the studies also the socio cultural and demographic variation within the countries.

In terms of brushing, $4 \%$ respondent used other method to clean their teeth which is greater than the study conducted by Amrita Mehta which reported it to be $2 \%$ and equal to Krishna Prasad who reported it to be $4 \%$,Our study reported $96 \%$ used brush to clean their teeth which was almost similar to the study conducted by Amrita Mehta reported it to be $95 \%$ According to the study $87.5 \%$ brushed their teeth only once in a day which is more than the study by Krishna Prasad i.e. 46.9\% and AnshulBagal i.e.54\%. The study showed $95.5 \%$ used zigzag and horizontal technique to brush their teeth which is greater than the study conducted by Amrita Mehta i.e.52\%. According to our study 87\% did not change their brush in correct frequency whereas a study conducted by Amrita Mehta reported it to $49 \%$.

Morever,23.5\% did not cleaned their tongue whereas $76.5 \%$ did, out of which $70 \%$ use tongue cleaner which was equal to the study conducted by Amrita Mehta reported it to be $75 \%$. This is attributed into tongue cleaning being a deeply rooted cultural practice in India. According to our study $47 \%$ children had bad eating habits which were more than a study done at Shashi Prabha who reported it to be $12 \%$. In our study only $0.5 \%$ visted dentist which was low than a study conducted by Anupriya Mehta S reported it to be $28 \%$.

Based on the finding the study suggests that the health professionals need to educate about avoiding the consumption of unusual substances and also need to emphasis about brushing technique frequency of brush changing and also the type of brush and make them understand the importance of visiting the dentist every 6 month. Which will therefore help them to maintain a good oral health status.

\section{CONCLUSIONS}

The present study indicates that, one third of study subjects have dental carries, plaque, fluorosis and moderate calculus. Oral hygiene practices found poor in the following area such as frequency of brushing, techniques of brushing, practice of rinsing mouth after meal, using tongue cleaner for cleansing of tongue, duration of brushing, type of tooth brush, frequency of changing tooth brush and visit of dentist. There was no much difference found in primary section and secondary section in terms of oral health status and oral hygiene practices. Hence present study suggests that, there is a need to create awareness on oral hygiene in order to improve oral health among school going children.

\section{ACKNOWLEDGEMENT}

"Gratitude is a miracle of its own recognition. It brings out a sense of appreciation and sincerity of a being".

It's our pleasure to extend our gratitude to all those who gave us the possibility, with their unconditional support and encouragement in every step of our study to complete this research. Working on this research would not have been 
possible without the support and encouragement that had been given to us by many people. The following people are the ones who have contributed more than many of them realize with due apology, to anyone who we might have missed we would like to thank the following people -

In the very beginning we would like to express our sincere thanks to "TO ALMIGHTY GOD" whose grace and blessings, we experienced throughout our study.

We would like to heartily express indebted thanks to our Principal, Prof. Dr. Rita Lakhani as well our research guide, Mrs. Deepa Reddy for their valuable guidance and support. I also extend our sincere thanks to Dr Ajay Mathur for provided training to assess the oral health status. We are very grateful for the feedback and the information given by them. Under their guidance and assistance, planning and development of the research work was done efficiently. We are also grateful that they have helped us with English editing of our research document. We sincerely express our gratitude to them for their timely support, till completion and submission of the study the encouragement and motivation provided by them was the reason behind the completion of the study.

We are thankful to the school authority and the teachers of Vangoan School for the permission to conduct the study and for their complete co-operation during the process and also for all study participants.

\section{REFERENCES}

1. GBD 2016 Disease and Injury Incidence, prevalence, and years lived with disability for 328 diseases and injuries for 195 countries, 1990-2016; a systematic analysis for the Global Burden of Disease study 2016. Lancet. 2017;390(10100): 1211-1259.

2. Shashi PrabhaTomar, Praddep Kumar Kasar, Rajesh Tiwari (2016). A cross sectional study of oral hygienic practices and oral health status among school children in Jabalpur, Madya Pradesh. International Journal of Community Medicine and Public Health. Vol.3, No:2.

3. Rabha, Arup Kumar, and SwargaJyoti Das. "Efficacy of Toothbrushes with and Without Dental Floss: A Comparative Study." International Journal of Dental Research \& Development (IJDRD) 6.2 (2016).

4. Benley George, Vinod Mathew Mulamottil. (2015). Oral health status of 5,12, \& 15 years-old school children in Tiruvalla, Kerala, India. Articles of Dentistry and Medical Research. Vol.3/issue:1/page 15-19.

5. National Commission of Macroeconomics and Health. Burden of Disease in India. 2005. Available from: http://www.who.int/macrohealth/.../NCMH_Burden. [Last accessed on 2014 May 12].

6. Amrita M, Siddhant P, Samved P, Suchetan P. The oral hygiene habits and general oral awareness in public schools in Mumbai. International Journal of Laser Dentistry. 2013; 3:60-7.

7. Garg S, Rubin T, Jasek J, et al. How willing are dentists to treat young children? Journal of American Dental Association. 2013;144 (4):416-425.

8. Hazari, Nida Fatima, and V. Vijaya Lakshmi. "Effectiveness of 2 D Animated Film on Nutrition and Ealth Practices of Rural Women. "International Journal of Communication and Media Studies (IJCMS) 7. 4, Oct 2017, 45-52

9. Dr. M. S. Minor Babu, Dr. SVSG Nirmala, Dr. N. Sivakumar. Oral Hygiene Status of 7-12 year old school children in Rural and Urban population of Nellore District. Journal of the Indian Association of Public Health Dentistry. Vol. 2011. Issue:`18. Suppl.III.

10. National Oral Health Survey and Fluoride Mapping. An Epidemiological Study of Oral Health Problems and Estimation of Fluoride Levels in Drinking Water. Dental Council of India: New Delhi. 2004; 32:67-78. 
11. Al-Asadi, Jasim Naeem. "Perceived stress and eating habits among medical students." International Journal of Medicine and Pharmaceutical Sciences 4 (2014): 81-90.

12. World Health Organization. World Oral Health Report 2003. Published 2003. Accessed 15 February, 2018.

13. Ramaiah, Pushpamala. "A study to assess the effectiveness of structured teaching program on the knowledge of lifestyle modification of hypertension among the patients with hypertension in a selected private hospital at Dharmapuri district." Int $J$ EducSci Res (IJESR) 5.1 (2015): 35-38.

14. Bulletin of the World Health Organization 2015; 93; 594-595. doi:http;/dx.doi.org/10.2471/BLT.15.020915.

Table I: Distribution of Demographic Data with Frequency and Percentage. N=200

\begin{tabular}{|c|c|c|c|}
\hline S. No & Variables & Frequency & Percentage \\
\hline 1 & $\begin{array}{l}\text { Gender: } \\
\text { Male } \\
\text { Female }\end{array}$ & $\begin{array}{c}103 \\
97\end{array}$ & $\begin{array}{l}51.5 \\
48.5\end{array}$ \\
\hline 2 & $\begin{array}{l}\text { Section: } \\
\text { Primary } \\
\text { Secondary } \\
\end{array}$ & $\begin{array}{c}119 \\
81 \\
\end{array}$ & $\begin{array}{l}59.5 \\
40.5 \\
\end{array}$ \\
\hline 3 & $\begin{array}{l}\text { Type of family: } \\
\text { Nuclear } \\
\text { Joint }\end{array}$ & $\begin{array}{c}88 \\
112 \\
\end{array}$ & $\begin{array}{l}44 \\
56 \\
\end{array}$ \\
\hline 4 & $\begin{array}{l}\text { Religion : } \\
\text { Hindu } \\
\text { Others }\end{array}$ & $\begin{array}{c}173 \\
27\end{array}$ & $\begin{array}{l}86.5 \\
13.5\end{array}$ \\
\hline 5 & $\begin{array}{l}\text { Socioeconomic status } \\
\text { (based on kuppu swami scale) } \\
\text { Upper lower class }\end{array}$ & 200 & 100 \\
\hline
\end{tabular}

Objectives 1: To assess oral health status among school going children.

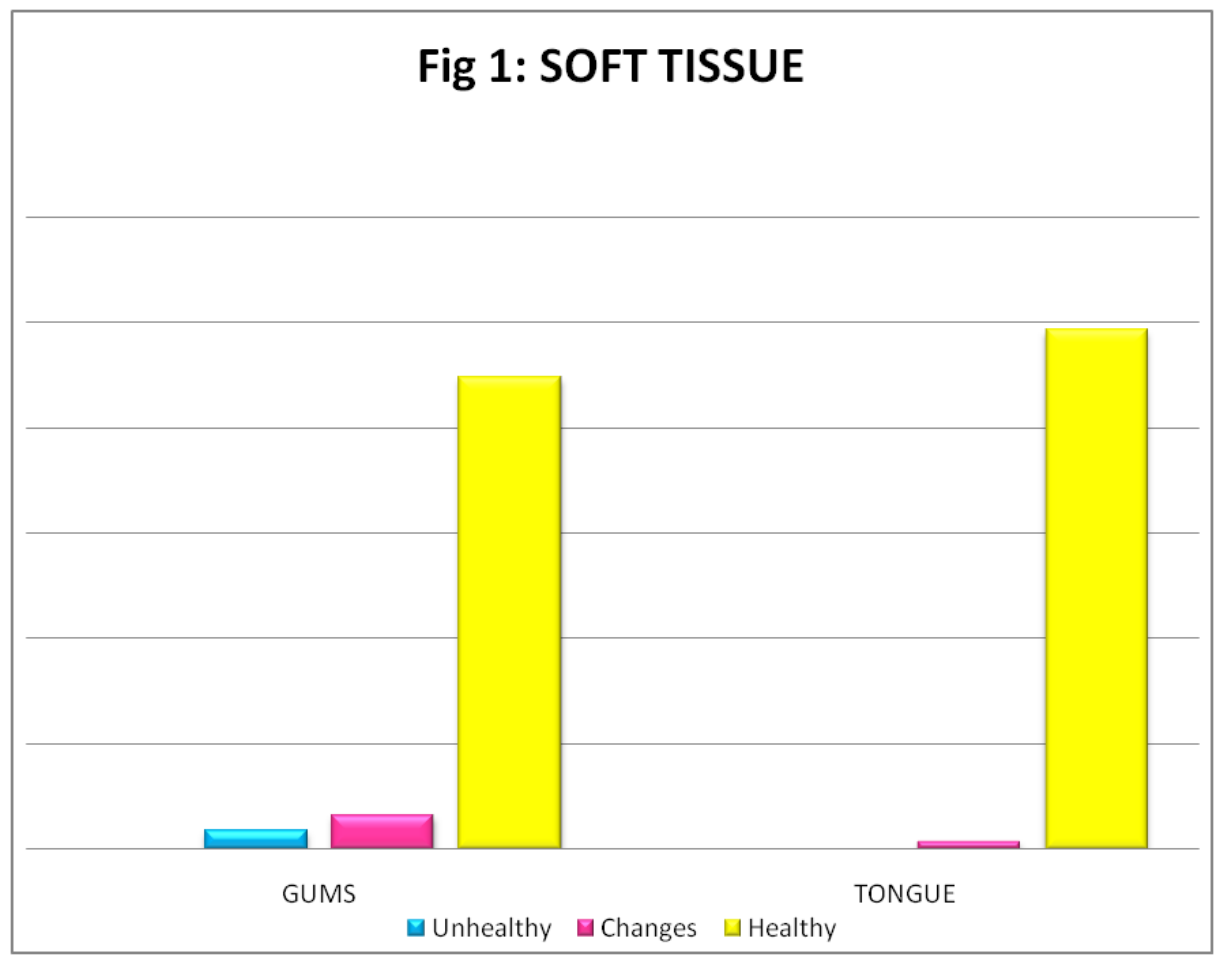




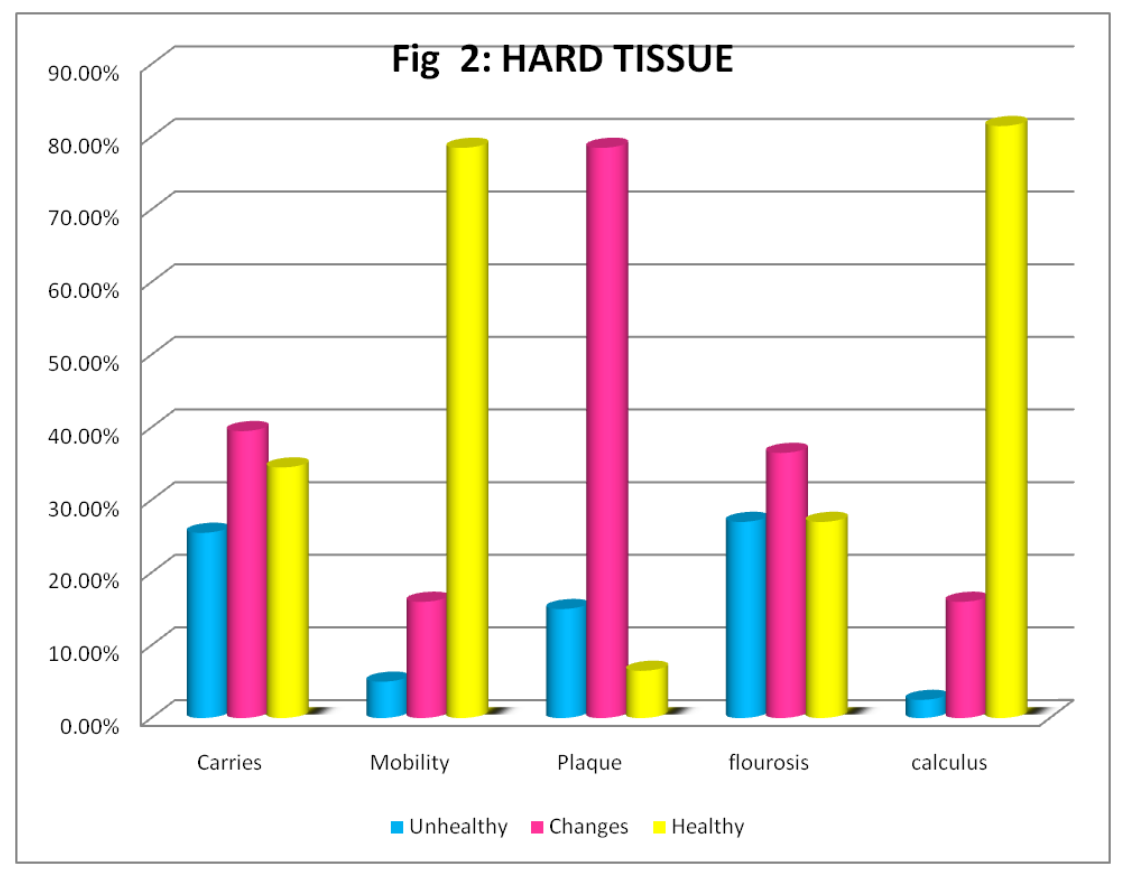

Table II: To assess oral hygiene practices among school going children.

\begin{tabular}{|c|c|c|c|}
\hline S. No & Variables & $\mathbf{F}$ & $\%$ \\
\hline 1 & $\begin{array}{l}\text { Material use to clean the teeth: Tooth brush and tooth paste } \\
\text { Others }\end{array}$ & $\begin{array}{c}192 \\
8\end{array}$ & $\begin{array}{c}96 \\
4\end{array}$ \\
\hline 2 & $\begin{array}{l}\text { Type of tooth paste: } \\
\text { Herbal } \\
\text { Non herbal }\end{array}$ & $\begin{array}{c}22 \\
178\end{array}$ & $\begin{array}{l}11 \\
89\end{array}$ \\
\hline 3 & $\begin{array}{l}\text { Frequency of brushing: } \\
\text { Twice in a day } \\
\text { Once in a day }\end{array}$ & $\begin{array}{c}25 \\
175 \\
\end{array}$ & $\begin{array}{l}12.5 \\
87.5\end{array}$ \\
\hline 4 & $\begin{array}{l}\text { Techniques of brushing: Circular } \\
\text { Other(zigzag, horizontal, vertical) }\end{array}$ & $\begin{array}{c}9 \\
191\end{array}$ & $\begin{array}{c}4.5 \\
95.5\end{array}$ \\
\hline 5 & $\begin{array}{l}\text { Practice for rinsing after meal: } \\
\text { Rinsed their mouth } \\
\text { Didn't rinsed their mouth. }\end{array}$ & $\begin{array}{c}136 \\
64\end{array}$ & $\begin{array}{l}68 \\
32\end{array}$ \\
\hline 6 & $\begin{array}{l}\text { Cleaning practice for tongue: } \\
\text { Yes } \\
\text { No }\end{array}$ & $\begin{array}{c}153 \\
47\end{array}$ & $\begin{array}{l}76.5 \\
23.5\end{array}$ \\
\hline 7 & $\begin{array}{l}\text { Tongue cleaning agent: } \\
\text { With tongue cleaner } \\
\text { With other }\end{array}$ & $\begin{array}{c}140 \\
60 \\
\end{array}$ & $\begin{array}{l}70 \% \\
30 \% \\
\end{array}$ \\
\hline 8 & $\begin{array}{l}\text { Fluoride content: } \\
\text { Present } \\
\text { Absent }\end{array}$ & $\begin{array}{l}90 \\
11\end{array}$ & $\begin{array}{l}45 \% \\
55 \%\end{array}$ \\
\hline S. No & Variables & $\mathbf{F}$ & $\%$ \\
\hline 9 & $\begin{array}{l}\text { Duration of brushing: } \\
1-3 \text { min } \\
<1 \text { min }\end{array}$ & $\begin{array}{c}44 \\
156 \\
\end{array}$ & $\begin{array}{l}22 \% \\
78 \% \\
\end{array}$ \\
\hline
\end{tabular}




\begin{tabular}{|c|c|c|c|}
\hline 10 & $\begin{array}{l}\text { Type of tooth brush: } \\
\text { Soft toothed } \\
\text { Other (hard, medium toothed) }\end{array}$ & $\begin{array}{c}87 \\
113\end{array}$ & $\begin{array}{l}43.5 \% \\
56.5 \%\end{array}$ \\
\hline 11 & $\begin{array}{l}\text { Frequency of changing brush: } \\
\text { Once in } 3 \text { months } \\
\text { Others (more than } 3,6 \text { months) }\end{array}$ & $\begin{array}{c}26 \\
174 \\
\end{array}$ & $\begin{array}{l}13 \% \\
87 \% \\
\end{array}$ \\
\hline 12 & $\begin{array}{l}\text { Bad habits of eating unusual substances: } \\
\text { No bad habit } \\
\text { Bad habit(chalk, mud) }\end{array}$ & $\begin{array}{c}106 \\
94 \\
\end{array}$ & $\begin{array}{l}53 \% \\
47 \% \\
\end{array}$ \\
\hline 13 & $\begin{array}{l}\text { Techniques to remove stuck food particles: } \\
\text { With toothpick } \\
\text { Others (sharp things) }\end{array}$ & $\begin{array}{c}81 \\
119\end{array}$ & $\begin{array}{l}40.5 \% \\
59.5 \%\end{array}$ \\
\hline 14 & $\begin{array}{l}\text { Halitosis: } \\
\text { Present } \\
\text { Absent }\end{array}$ & $\begin{array}{c}138 \\
62 \\
\end{array}$ & $\begin{array}{l}69 \% \\
31 \% \\
\end{array}$ \\
\hline 15 & $\begin{array}{l}\text { Visit to dentist: } \\
\text { Regularly(once in } 6 \text { month) } \\
\text { Not regularly }\end{array}$ & $\begin{array}{c}1 \\
199\end{array}$ & $\begin{array}{c}0.5 \% \\
99.5 \% \\
\end{array}$ \\
\hline
\end{tabular}

\section{Oral Health Assessment Tool for Dental Screening}

\begin{tabular}{|c|c|c|c|c|c|}
\hline & Category & $0=$ healthy & $1=$ changes & $2=$ unhealthy & Score \\
\hline \multirow[t]{2}{*}{$\begin{array}{l}\text { Soft } \\
\text { tissue }\end{array}$} & $\begin{array}{l}\text { Gum } \\
\text { Tissue }\end{array}$ & Pink, moist & Rough, red & Swollen,bleeding & \\
\hline & Tongue & $\begin{array}{l}\text { Normal, } \\
\text { pink }\end{array}$ & Patchy, red & Ulcerated red or pink & \\
\hline \multirow{5}{*}{$\begin{array}{l}\text { Hard } \\
\text { tissue } \\
\text { (teeth) }\end{array}$} & Carries & No decay & 1 or3 & More than 3 & \\
\hline & Mobility & No Mobility & $1^{\text {st }}$ and $2^{\text {nd }}$ degree & $3^{\text {rd }}$ degree & \\
\hline & Plaque & No Plaque & $\begin{array}{l}\text { Film of plaque margin, moderate } \\
\text { soft deposit }\end{array}$ & Abundance of soft deposit & \\
\hline & Fluorosis & $\begin{array}{l}\text { No } \\
\text { evidence }\end{array}$ & White patches on tooth surface & $\begin{array}{l}\text { Brownish discoloration of tooth } \\
\text { surface }\end{array}$ & \\
\hline & Calculus & No calculus & Slightly traceable & Moderate & \\
\hline
\end{tabular}


